\title{
Archaeology in a Stockholm Perspective - a Personal Reflection
}

\author{
Åke Hyenstrand
}

\begin{abstract}
This paper presents a short sketch over Swedish archaeology from a Stockholm perspective. It starts from Montelius and leads via "New Archaeology" to a comment on the interpretive aspect of archaeology.
\end{abstract}

Ake Hyenstrand, Department of Archaeology, Stockholm University. S-l06 91 Stockholm. Sweden.

Archaeology in Scandinavia emanates primarily from a "classical" European tradition. This implies that ties with anthropology have been weak while ties with art history and history have been traditionally stronger. "New Archaeology" (NA) experienced a great breakthrough here during the 1970s. This brought about a certain conflict, not least in Denmark. In Sweden, NA was accepted in antiquarian circles which contributed to a calmer development. "Traditional" archaeology, however, still holds a strong position in archaeological work and activity in Sweden today.

Sweden and Scandinavia are marginal areas in relation to the Eurasian Continent. In Scandinavia the archaeological source material is both well preserved and well documented. Legislation for the care, preservation and protection of ancient and historical monuments is strong. Archaeology holds a well integrated and stable position in future planning and exploitation in Sweden. Computers (ADB) are used to a certain extent. Research and education are carried out at five different universities: Stockholm, Uppsala, Lund, Gothenburg and Umeå. The majority of archaeological work is carried out by the Central Board of National Antiquities (Riksantikvarieämbetet), that is to say, within the antiquarian section. Approximately 50 million Sw crowns are used annually for rescue archaeology. In addition, Sweden's Ancient Monuments Register is unique in world archaeology.
These factors, that is Sweden's marginal location, the source material, the size of the country and the possibilities for carrying out studies covering long periods of time, for example from the mesolithic and on, have influenced and directed the questions and problems in research. Local variations and the processes of change have been the objects of research. There is a strong interest in historical questions of the kind that treat the early establishment of the State, problems concerning trade and commerce, as well as in medieval towns and landscape.

Seen in a longer perspective, the country's archaeology can be divided into three phases. In the first phase, about 100 years ago, the museum tradition was created. Oscar Montelius typological system of artifacts gave Swedish archaeology a world reputation. Simultaneously research became tied to authority.

Phase two, the period following WWII, is characterized by an enormous increase of archaeological source material, primarily through rescue archaeology. A large collection of artifacts was accumulated, and the need for research and analysis created the prerequisites for NA. Research intentionally directed towards settlement studies was established (Björn Ambrosiani as well as within Human Geography). At the same time, a necessary clarification of the basic principles of typology was worked out (Mats P. Malmer). Malmer stood close to NA, especially in the form it 
was later given by David Clarke. Even CarlAxel Moberg, who had strong international interests, became a pioneer for NA.

Traditional archaeology on a Montelian foundation is still well established within the museums. NA has partially made a complete breakthrough at the Central Board of National Antiquities.

The problem in research, that is the connection between theory and source material, is well recognized in Sweden. The application of NA has been successful and modernized the country's archaeology. Within the universities there is today a reaction against NA. Many students feel that NA has not succeeded in providing the kind of explanations for source material which lead towards understanding. In Stockholm this tendency is clearly noticed in critical discussions which lead to a widening of both arguments and interpretations; this is the third phase, closely related to post-processuall archaeology.

There is a division then between those who see archaeology as a problem of reconstruction and those who see archaeology as a problem of interpretation. The first attitude seems to characterize those who are engaged in rescue archaeology, the latter attitude is anchored within the university, particularly in the younger research generation. These deny the possibility that analysis and study of a source material in itself lead to a given interpretation of prehistory: "how it really was". This means that one and the same source material can be given different interpretations depending upon which theoretical perspective is being used. This also means that documentation cannot be separated from interpretation when seeking knowledge.

Translated by Phyllis Anderson.

This paper was presented to professor Lewis $R$ Binford as an introduction in connection with his visit in Stockholm in April 1990. 